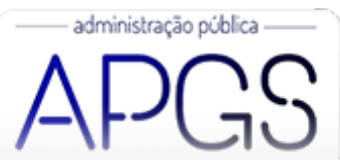

Administração Pública e Gestão Social ISSN: 2175-5787

apgs@ufv.br

Universidade Federal de Viçosa

Brasil

\title{
Propensity to Corrupt Decisions of Pre- Candidates to the 2020 Brazilian Municipal Elections
}

Schneider Hahn, Ivanete; Schleder Cezar Bonatti, Eliane; Mattos Martins, Anderson Antônio Propensity to Corrupt Decisions of Pre-Candidates to the 2020 Brazilian Municipal Elections

Administração Pública e Gestão Social, vol. 14, núm. 1, 2022

Universidade Federal de Viçosa, Brasil

Disponible en: https://www.redalyc.org/articulo.oa?id=351569604002

\section{(c) (1) $(9)$}

Esta obra está bajo una Licencia Creative Commons Atribución-NoComercial-SinDerivar 4.0 Internacional. 


\title{
Propensity to Corrupt Decisions of Pre-Candidates to the 2020 Brazilian Municipal Elections
}

\author{
Propensão à Decisões Corruptas de Pré-Candidatos às Eleições Municipais de 2020 \\ Propensidad de Corrupción entre los Precandidatos a las Elecciones Municipales Brasileñas de 2020
}

Ivanete Schneider Hahn

Universidade Alto Vale do Rio do Peixe (Uniarp), Brasil

Redalyc: https://www.redalyc.org/articulo.oa?

ivischneider@hotmail.com

Eliane Schleder Cezar Bonatti

Universidade Alto Vale do Rio do Peixe (Uniarp), Brasil

eliane.schleder18@gmail.com

Anderson Antônio Mattos Martins

Universidade Alto Vale do Rio do Peixe (Uniarp), Brasil

andersonmartins@uniarp.edu.br

Recepción: 11 Diciembre 2020

Aprobación: 08 Agosto 2021

Publicación: 08 Enero 2022

\section{ReSUMEN:}

Objetivo de la investigación: analizar la propensión a las decisiones corruptas de los precandidatos a alcalde (a) y concejal (a), utilizando las elecciones municipales de 2020 como extracto de análisis.

Marco teórico: el estudio se basa teóricamente en el aspecto conductual de la corrupción, como conducta desviada, así como las motivaciones intrínsecas y extrínsecas a la corrupción, las cuales se subdividen en: propensión a la toma de decisiones poco éticas, autocontrol individual, identidad moral, culpa y desvinculación moral. Este aspecto conductual de la corrupción está respaldado en el artículo en la teoría de la agencia y la teoría de la elección pública.

Metodología: Se realizó un estudio cuantitativo, exploratorio y descriptivo. En la operacionalización se utilizó una encuesta transversal y los datos se recolectaron a través de un cuestionario estructurado aplicado a una muestra válida de 115 precandidatos para las elecciones municipales de 2020. El análisis de los datos utilizó técnicas estadísticas univariadas y bivariadas.

Resultados: los datos muestran que: (1) una muestra con baja propensión a la toma de decisiones poco éticas, alto autocontrol individual, alta identidad moral, baja culpa y baja propensión a la desvinculación moral; (2) existe una asociación significativa y positiva entre las variables de autocontrol individual con culpa, desvinculación moral; y se muestra que la identidad moral se asocia positivamente con la desvinculación moral, y la desvinculación moral positivamente con la variable de tener o no un cargo electivo previo.

Originalidad: El principal aporte de la investigación es el análisis del tema sobre legisladores y ejecutores municipales, en la versión de precandidatos.

Contribuciones teóricas y prácticas: (1) baja representación de mujeres incluso como precandidatas; (2) la muestra considera a los "otros" políticos predispuestos a tomar decisiones no éticas, pero no a ellos mismos; (3) muestra con alta capacidad de autocontrol, especialmente la parte de la muestra que no ocupaba un cargo electivo previo; (4) las mujeres tienen un mayor grado de culpabilidad que los hombres, es decir, son menos propensas a tomar decisiones que atenten contra los preceptos éticos y morales, o incluso la corrupción; (5) se puede decir que la muestra tiene poca propensión a comportamientos desviados, es decir, corrupción.

Palabras clave: Conductas desviadas, Toma de decisiones poco ética, Autocontrol individual, Identidad moral, Separación moral.

\section{ABSTRACT:}

Objective: to analyze the propensity for corrupt decision-making by pre-candidates for mayor and councilor, analyzing the 2020 Brazilian municipal elections.

Theoretical framework: the study is based on the behavioral aspect of corruption, as deviant behavior, and intrinsic and extrinsic motivations to corruption, which are subdivided into a propensity to unethical decision-making, individual self-control, moral 
identity, guilt, and disengagement moral. This behavioral aspect of corruption is supported in the Agency Theory and Theory of Public Choice article.

Methodology: A quantitative, exploratory, and descriptive study. A cross-sectional survey was used in the operationalization, with the data collected through a structured questionnaire applied to a valid sample of 115 pre-candidates for the 2020 municipal elections. The data analysis used univariate and bivariate statistical techniques.

Results: (1) a sample has a low propensity for unethical decision-making, high individual self-control, high moral identity, low guilt, and low propensity for moral disengagement. (2) there is a significant and positive association between the variables of individual self-control with guilt. Moral disengagement and moral identity are shown to be associated with moral disengagement. Moreover, moral disengagement positively with the variable of having a previous elective position or not.

Originality: The main contribution of the research is the analysis of the theme on municipal legislators and executors in the version of pre-candidates.

Theoretical and practical contributions: (1) low representation of women even as pre-candidates; (2) the sample considers the 'other' pre-willing politicians to make unethical decision-making, but not themselves; (3) sample with a high capacity for selfcontrol, especially the part of the sample that did not have a previous elective position; (4) women have a higher degree of guilt than men, that is, they are less disposed to unethical decisions or corruption; (5) it can be said that the sample has a low propensity to deviant behaviors, that is, corruption.

KEYWORDS: Deviant behaviors, Unethical decision-making, Individual self-control, Moral identity, Moral disengagement.

\section{Resumo:}

Objetivo da pesquisa: analisar a propensão para decisões corruptas, considerando os pré-candidatos à prefeito(a) e vereador(a), utilizando como recorte de análise as eleições municipais 2020.

Enquadramento teórico: o estudo se sustenta na vertente comportamental da corrupção, enquanto comportamento desviante, bem como das motivações intrínsecas e extrínsecas à corrupção, sendo subdividas em: propensão a tomada de decisão antiética, autocontrole individual, identidade moral, culpabilidade e desengajamento moral. Essa vertente comportamental da corrupção é sustentada no texto pela Teoria da Agência e Teoria da Escolha Pública.

Metodologia: Foi conduzido um estudo quantitativo, exploratório e descritivo. Na operacionalização, utilizou-se uma survey de corte transversal, sendo os dados levantados por meio de um questionário estruturado aplicado a uma amostra válida de 115 précandidatos às eleiçôes municipais de 2020. A análise dos dados utilizou técnicas estatísticas univariadas e bivariadas.

Resultados: (1) baixa propensão a tomada de decisão antiética, alto autocontrole individual, identidade moral alta, culpabilidade baixa e baixa propensão ao desengajamento moral; (2) existe uma associação significativa e positiva entre as variáveis de autocontrole individual com culpabilidade, desengajamento moral; e a identidade moral se mostra associada positivamente ao desengajamento moral, já o desengajamento moral positivamente com a variável de possuir cargo eletivo anterior ou não.

Originalidade: A principal contribuição da pesquisa está na análise da temática sobre os legisladores e executores municipais, na versão de pré-candidatos.

Contribuições teóricas e práticas: (1) baixa representatividade das mulheres inclusive enquanto pré-candidatas; (2) a amostra considera os 'outros' políticos pré-dispostos a tomada de decisão antiética, mas não eles próprios; (3) amostra com alta capacidade de autocontrole, especialmente a parte da amostra que não ocupou um cargo eletivo anterior; (4) as mulheres possuem maior grau de culpabilidade que os homens, isto é, são menos propensas a decisões que firam os preceitos éticos e morais, ou ainda, a corrupção; (5) pode-se dizer que a amostra possui baixa propensão a comportamentos desviantes, isto é, de corrupção.

Palavras-chave: Comportamentos desviantes, Tomada de decisão antiética, Autocontrole individual, Identidade moral, Desengajamento moral.

\section{INTRODUCTION}

The fight against corruption has been a banner for a large part of the elected political class in recent years, and even so, there are few concrete measures to face the problem. In Brazil, the government supported no compelling anti-corruption reform agenda, and serious institutional setbacks took place. Furthermore, the advance of authoritarianism, with attacks on journalists and civil society, represents another threat to the fight against corruption. In 2020, with the rise of the Covid-19 pandemic, the risk of corruption increased. Countless corruption cases worldwide showed their most perverse consequences amid the terrible humanitarian crisis (IPC, 2020). 
All these issues directly impact the Corruption Perception Index (CPI), an index in which, in 2020, Brazil was stagnant (considering the research's margin of error) at an appalling level, below the average of the BRICS, below the regional average for Latin America and the Caribbean and below the world average and still far from the average of the G20 and OECD countries (IPC, 2020). Data from the IPC (2019) show that corruption is more frequent in countries with power and money, especially in electoral campaigns.

When conceptualizing the phenomenon of corruption, it can be observed that it does not have a single concept, considering that it can be analyzed under different perspectives: social, economic, or historical, or under the prism of law, in the criminal sphere, civil and administrative (Gabardo \& Reis, 2011). In this article, corruption refers to the "abusive use of a resource, power or position inherent to its functions by a public or private agent. The practice of any act or omission implying the violation of duties is also considered corruption" (Cunha, 2014, p. 45). Corruption is thus closely linked to political representation and delegation of power to elected politicians in democratic systems (Batista, 2013).

Thus, the spread of corruption has turned the issue into one of the main agendas of democratic countries (Batista, 2013). Corruption has also raised increasing interest from researchers in different areas of knowledge (Modesto, 2018). Most studies on the subject have sought to analyze possible articulations and motivations between deviant behavior and the occurrence of corrupt practices in public sector organizations (Carlos, Ribeiro, \& Cintra, 2020; Macedo \& Valadares, 2020; Medeiros \& Forte, 2019; Medeiros \& Freitas, 2019; Sodré, 2017; Souza et al., 2019). In some way, these studies show unethical and corrupt motivations of public agents in common and bring possibilities to reduce these practices, as is the example of transparency mechanisms.

A field of research has been established by Batista (2013) and Rodrigues and Rodrigues (2020), Andrade (2018), and Albuquerque and Ramos (2006) by looking at politicians and the effects of corruption on electoral succession. These surveys found that factors such as reelection (mayors in their second term commit more corrupt acts than in the first term) and victory margin (the more significant the mayor's margin of victory (the less competitive the election) increase corruption (Batista, 2013). Andrade (2018), in turn, shows that the determining variables for the success of reelection are: transfers from the federal government, the mayor's political support base (share vote), and the existence or not of an episode involving the diversion of public resources. Mayors who adopt good governance practices tend to be re-elected (Rodrigues \& Rodrigues, 2020).

In other spheres, Luciano, Wiedenhöft, and Callegaro (2019) identified that a country that is less bureaucratic, more democratic, more transparent, and where institutions work better is more protected from the occurrence of corruption, considering that these four variables act as a deterrent to corruption. Araújo et al. (2020) present a theoretical discussion about the relationship between corruption in accounting, the "Brazilian way," and its implications for companies - without, however, bringing empirical results.

When analyzing the existing literature, as far as is known, studies that deal with corruption do not specifically address political agents at the micro-level, that is, municipal legislators. The scope of corruption is due to the propensity and involvement of people with corrupted actions (individual behavior), which are directly influenced by their perspectives and by the social interaction in the environment in which they are inserted (Den Nieuwenboer \& Kaptein, 2008; Tavits, 2010).

Even if municipal political agents are supervised by the Office of the Controller General of the Union (CGU), The probability of being audited should discourage them from committing irregularities (Gomes, 2013; Andrade, 2018). Thus, this article analyzes the propensity for corrupt decisions of pre-candidates for mayor and councilor, using the 2020 municipal elections in 16 municipalities in the Midwest of Santa Catarina as an analytical framework. Therefore, this study contributes by not focusing on the actions of public bodies but the behavior of municipal legislators.

This article is organized into seven sections. This first section sought to contextualize the importance of the topic, define it, point out available studies on the subject, the research gap, and how this article seeks 
to respond to this gap. Then, the theoretical foundations are presented, covering the theme of corruption, deviant behavior, corrupt decisions, and corruption's intrinsic and extrinsic motivations. Afterward, the methodological path, results, and discussions are presented. Finally, limitations and recommendations for future research are presented.

\section{Corruption, DEVIANT BeHAVIOR, AND CORRUPt DECisions: ANALYSis From AgenCy Theory and Public Choice Theory}

In its definition, corruption refers to an act or effect of corrupting and should be treated as a constant concern for democracy. Corruption is closely related to ethical principles, which are defined as the rules that define behavior (Bartels, 1967), being developed from the development of cognitive morality, evaluating the behaviors of a system of norms (Blasi, 1980; Kohlberg, 1969) The people involved creating a justifiable explanation for such an act, highlighting how their good intentions minimize the harmful consequences of their choices (Rabl \& Kuhlmann, 2009). Thus, "corrupt behavior is a consequence of failures that are generated in the intrinsic decision-making process of each person" (Bandura, 1986:1; Tenbrunsel \& Messick, 2004:1)

When corruption is analyzed from the individual's perspective, one can look for explanations of its motivations in the Agency Theory, which is based on the seminal studies of Jensen and Meckling (1976) and Eisenhardt (1989). The Agency Theory seeks to explain the relationship between two or more individuals, where "one of these two individuals is an agent of the other, called the principal," where the agent "commits to perform certain tasks for the principal and the principal commits themselves to remunerate the agent" (Hendriksen \& Van Breda, 1999, p. 139). The theory argues that it is almost impossible to ensure that the agent (in the case of this research - political agents) makes the best decision from the principal's point of view (the population), as this agent always seeks to maximize its utility.

It is necessary to understand politics as a process of exchange. The agents of these exchanges - politicians and bureaucrats - must be analyzed as holders of a utilitarian behavior like what they would have if they had acted in the economic sphere (Araújo \& Sanchez, 2005).

The Public Choice Theory should be cited by incorporating this behavioral premise (self-interest) to explain the political process. The theory argues that the choice of public agents cannot be expected to be identified with the pursuit of the common good (Buchanan, 1985; Araújo \& Sanchez, 2005).

Power acts by changing the behavior of individuals in different ways, interfering with their decisionmaking execution (Bendahan et al., 2017; Sturm \& Antonakis, 2015). According to Da Matta (1982, p. 1), it is crucial to abandon linear perspectives to understand themes such as violence, crime, and deviance. It is impossible to identify a single cause or origin for the facts. Becker (2008) explains that deviation is not a simple quality, present in some types of behavior and absent in others. However, it is the product of a process that involves reactions and interpretations of other people to behavior that is in focus. The deviation comes from the interaction between the person who commits it and the one who reacts to it (Becker, 2008:27).

Corruption is, therefore, an agent that alters the development of a country, state, and municipality, affecting its social development and the quality of life of its population that resides there (Luciano, Wiedenhoft, \& Callegaro, 2019). Therefore, understanding corruption as an organizational phenomenon is essential. It is also essential to enter the sociological contexts to improve understanding from the perspective of individual interpretations of public managers (Medeiros \& Freitas, 2019).

Against this backdrop, corruption can be understood as a form of culture by the people who practice it. At the same time when the norms to fight corruption are absorbed by society. It will be challenging to combat the motivations that lead people to be involved with corruption. That is, individuals who grow up in societies where corruption predominates will probably accept it more easily, taking the practice of it (Medeiros \& Freitas, 2019). 
Countless problems transpose the field of study on corruption, such as, for example, high-level members, tenders and contracts, public works, and electoral campaigns (Souza, Silva \& Gomes, 2019). The same authors (2019) explain that in most studies, the focus of the authors is not necessarily related to the issue or object of corruption, but to the institutional changes that are caused, and the mechanisms related to combating, preventing, or tolerating it, regardless of the reform and its purposes.

Regarding the circumstances that lead agents to deviant behavior and corrupt decisions, Dorminey et al. (2012 apud Carlos, 2019) described that at least three factors are necessary for their involvement: motivation, opportunity, and rationalization. These factors reduce the feeling of guilt and disapproval for the commission of such an act illegal. As the focus of this study is on propensity, which comes from motivations, the following section provides a theoretical framework on the subject.

\section{INTRINSIC AND EXTRINSIC MOTIVATIONS TO CORRUPTION}

Most studies seek to create mechanisms to combat corruption focus on creating controls, monitoring, and punishments as the primary measures. Punishment increases generate an increase in cooperative behavior in people and are, therefore, the most important formal mechanisms for preventing corruption (Frost $\&$ Tischer, 2014). On the other hand, several studies use control and sanctions as part of a package of measures that need to be taken together to effectively reduce corrupt behavior and not just put it to sleep (Donato, 2018; Lange, 2008; Úbeda \& Guzmán,2010).

New studies show that intrinsic and extrinsic motivations related to deviant behavior can be subdivided into secondary dimensions: perception of unethical decision-making, self-control, moral identity, and culpability (Carlos, 2019).

Initially, lack of self-control has been indicated as a predictor of criminal behavior. Criminals with low control over their attitudes tend to focus on the immediate benefit generated by the commission of the criminal act, giving less importance to the future consequences of their actions (Mead et al., 2009). Individuals with a high propensity for guilt tend to value moral and ethical traits (Köbis et al., 2016). Also, according to Veloso Gouveia et al. (2013), the constancy of self-control would explain why antisocial behaviors are so immutable throughout life. Those individuals who commit a significant number of deviant behaviors during childhood are more likely to continue with such behaviors at other times in life.

Moral identity, in turn, refers to the intra-individual property, which directs cognitions to the process of self-regulation, moderating the censorship and behavior used in its decision-making process (Moore, 2008). Resende and Porto (2017, p. 75) explain that "stages develop morality throughout life in which men stop responding only according to the rules until they are sure about what is right or wrong. Moral identity is not stable; it changes insofar as there is a stimulus or not for this type of behavior." Not all moral behavior is intentional because, in many circumstances, this way of behaving is automatic; its honesty comes from a previous experience in which there is unconscious processing of information (Reynolds \& Ceranic, 2007).

Thus, according to Aquino and Reed (2002), an individual's moral identity may be associated with certain attitudes, beliefs, and behaviors. The central argument is that morality is central to the subject despite each individual's variations in moral aspects. It enables action through responsibility and conscience (Blasi, 1984). The perceptions of unethical decision-making are justified as a motivator of corruption in the assumptions of Ferrell and Gresham (1985). They found that the behavior is influenced when there is an opportunity to do something wrong and unethical. The factors influence ethical or unethical decision-making.

The feeling of guilt arises when a person performs or even intends to do something not ethical (Aquino \& Medeiros, 2009). For the authors, objective guilt occurs when a law is broken, and the transgressor is found guilty, even if he does not feel guilty.

Finally, people with a greater propensity to morally disengage will make unethical decisions more efficiently. In this case, the reverse is true, so they usually coincide when criminal action is underway 
(Abraham, Suleeman, \& Takwin, 2018; Moore, 2008). Through moral disengagement, individuals feel free to self-penalize and feel guilty when their behavior violates proper standards. Therefore, they are more likely to make unethical decisions (Detert, Treviño \& Sweitzer, 2008).

\section{Methodological Path}

We have used exploratory and descriptive research with quantitative methods for data analysis. Furthermore, the assumptions of the survey design were followed. As a characteristic of this method, the interest is to carry out quantitative information on a sample (Freitas et al., 2000). According to Hair et al. (2005), survey research collects primary data from a representative sample of individuals. For operationalization, a structured questionnaire was used as a data collection instrument. The collection instrument was organized into 55 observable variables and divided into six blocks, as explained below:

1. For the Socioeconomic profile of respondents: eight open and closed questions, namely: gender, age, income, profession, education, marital status, religion, and ethnicity.

2. Respondents' perceptions of unethical decision-making: four statements, using the ethical compliance scale proposed by Pelletier and Bligh (2006), with questions built from the Likert scale (that is, ranging from 1 - I totally disagree to 5-totally agree). This model was developed by Rensis Likert (1932) to measure attitudes in the context of behavioral sciences.

3. Individual self-control: six observable variables that include multiple factors of their own that together make a person tend (or not) to consent to delinquency (Veloso Gouveia et al., 2013). Thus, this scale was adapted from Veloso Gouveia et al. (2013), and the questions were measured using a Likert scale.

4. For the pre-candidate's moral identity: eight statements adapted from Resende and Porto (2017) were used using a Likert scale.

5. Culpability: eight statements adapted from the Aquino and Medeiros scale (2009) with questions measured using the Likert scale.

6. For Moral Disengagement: eleven questions adapted from the scale of Detert, Trevino, and Sweitzer (2008), were used measured by a Likert scale.

The study population of this research refers to pre-candidates for the municipal election in 2020. We opted for a non-probabilistic sampling, for convenience, with a single cross-section, which offers an overview of a given moment according to Hair et al. (2005). In order to make the data collection feasible, considering that it took place at the time of the Covid-19 Pandemic, it was decided to geographically locate the research locus for 16 municipalities in the midwest of Santa Catarina, all located within a radius of $150 \mathrm{~km}$ from Caçador/ SC, namely: Arroio Trinta, Lebon Régis, Calmon, Canoinhas, Campos Novos, Curitibanos, Correia Pinto, Fraiburgo, Iomerê, Major Vieira, Ponte Alta do Norte, Salto Veloso, Timbó Grande, and Videira. This region was chosen for accessibility.

The self-administered online questionnaire was sent using e-mail, WhatsApp, and other networks. The questionnaire was initially sent to the political party directories in each municipality, with the data found available on online websites. In addition, it was forwarded to political representatives known to the researchers, who forwarded them to their relationship networks. As the number of pre-candidates was unknown to obtain a sample, we worked from the number of respondents, with 169 . However, after cleaning the database (where incomplete, inconsistent, or critical questionnaires were excluded in the comments and questionnaires of non-pre-candidates), a final sample of 115 valid questionnaires was obtained. Data collection took place between the beginning of August and mid-September 2020 (the date the candidates were announced - they were no longer pre-candidates). Table 1 shows the profile of survey respondents. 


\begin{tabular}{|c|c|c|}
\hline Age & Between 18 and 70 years old & $\begin{array}{c}\text { Average } 43 \\
\text { year old }\end{array}$ \\
\hline \multirow{3}{*}{ Gender } & Male & $73,9 \%$ \\
\hline & Female & $25,2 \%$ \\
\hline & Prefer not to answer & $0,9 \%$ \\
\hline \multirow{4}{*}{ Marital Status } & Married/Stable Union & $68,7 \%$ \\
\hline & Divorced/Separated & $14,8 \%$ \\
\hline & Single & $14,8 \%$ \\
\hline & Widow/widower & $1,7 \%$ \\
\hline \multirow{5}{*}{$\begin{array}{l}\text { Education } \\
\text { Level }\end{array}$} & Elementary School (till Sth grade) & $6,9 \%$ \\
\hline & High school & $54,8 \%$ \\
\hline & Bachelor Degree & $9,6 \%$ \\
\hline & Postgraduate (specialization or MBA level) & 26,1 \\
\hline & Postgraduate degree (at master's or doctoral level) & 2,6 \\
\hline \multirow{5}{*}{$\begin{array}{l}\text { Family } \\
\text { Income }\end{array}$} & Until 2 minimum salaries (up to RS $2.090,00$ ) & $1,9 \%$ \\
\hline & From 2 to 6 minimum salaries (between $R \$ 2.090,01$ and $R \$ 6.270,00$ ) & $53,9 \%$ \\
\hline & From 6 to 10 minimum salaries (between RS6.270,01 and R\$10.450,00) & $16,5 \%$ \\
\hline & From 10 to 14 minimum salaries (between RS10.450,01 and RS14.630,00) & $5,2 \%$ \\
\hline & More than 14 minimum salaries (Minimum of $\mathrm{R} \$ 14.630,01$ ) & $10,4 \%$ \\
\hline \multirow{6}{*}{ Religion } & Catholic (Ortodox, Roman) & $68,8 \%$ \\
\hline & Assembly of God, Foursquare, Universal & $16,6 \%$ \\
\hline & Spiritist & $6,1 \%$ \\
\hline & Protestant (Adventist, Baptist, Lutheran) & $3,5 \%$ \\
\hline & No religion & $1,7 \%$ \\
\hline & Other & $3,3 \%$ \\
\hline \multirow{4}{*}{ Ethnicity } & White & $80,9 \%$ \\
\hline & Indigenous & $0,9 \%$ \\
\hline & African-American & $3,5 \%$ \\
\hline & African American/Indian & $14,8 \%$ \\
\hline \multirow{6}{*}{ Profession } & (Signed Portfolio) & $11,3 \%$ \\
\hline & Freelance & $25,2 \%$ \\
\hline & Businessperson & $24,3 \%$ \\
\hline & Retired & $3,5 \%$ \\
\hline & Public official/employee & $30,4 \%$ \\
\hline & Student/ not working & $5,2 \%$ \\
\hline Age & Between 18 and 70 years old & $\begin{array}{c}\text { Average } 43 \\
\text { year old }\end{array}$ \\
\hline \multirow{3}{*}{ Gender } & Male & $73,9 \%$ \\
\hline & Female & $25,2 \%$ \\
\hline & Prefer not to answer & $0,9 \%$ \\
\hline \multirow{4}{*}{ Marital Status } & Married/Stable Union & $68,7 \%$ \\
\hline & Divorced/Separated & $14,8 \%$ \\
\hline & Single & $14,8 \%$ \\
\hline & Widow/vidower & $1,7 \%$ \\
\hline Education & Elementary School (till 8th grade) & $6,9 \%$ \\
\hline
\end{tabular}

As it can be seen, the sample is composed mainly of men (73.9\%), married or in a stable relationship (68.7\%), Catholics (68.8\%), white (80.9\%), with education divided between complete high school (54.8\%), postgraduate studies at the specialization level and MBA $(26.1 \%)$, and the average age of 43 years. These data approximate the average profile of candidates in the 2020 election in Brazil. Data from the Superior Electoral Court, published by the G1 (2020), show that the average profile of the candidate in the elections is a man, 46 years old, black, married, and with high school education. The issue that differs in this sample is ethnicity, as our sample is predominantly white, which may be characteristic of the region used as the locus.

Data analysis was performed using statistical techniques, using the SPSS Statistics 21 Software. Initially, the data entry matrix preparation was carried out, where missing values, outliers, and the normality of the data distribution were analyzed in the preparation step.

After adjusting the data's normality and scale reliability, a descriptive, univariate, and bivariate analyses were carried out. The descriptive and univariate analysis presents the mean, standard deviation, minimum and maximum values of the frequency of behaviors. The data's bivariate analysis, differences between groups (performed using the One-Way Anova test), and Pearson's correlation test are presented to measure the statistical relationship between the dimensions studied. 


\section{Results}

In this section, we present the univariate analysis of the dimensions and the descriptive and univariate analyses. The mean, standard deviation, and frequency distribution by scale intensity level are included in the appendix.

Table 2: Univariate analysis of dimensions

\begin{tabular}{lll}
\hline Dimension & Mean & $\begin{array}{l}\text { Standard } \\
\text { Deviation }\end{array}$ \\
\hline Unethical decision making & 2,56 & 0,580 \\
\hline Individual self-control & 3,07 & 0,535 \\
\hline Moral identity & 3,41 & 0,828 \\
\hline Culpability & 2,90 & 0,864 \\
\hline Moral disengagement & 1,86 & 0,583 \\
\hline
\end{tabular}

Source: Research Data.

In analyzing the dimension perception of unethical decision-making, $79 \%$ of respondents believe that other politicians let themselves be carried away by whims, passions, or personal interests in dealing with the public or other colleagues (average 4.05). 73\% believe that other politicians have deliberately damaged the reputation of other servants or citizens who depend on them. Respondents believe that other politicians treat public service users differently, according to the user's social or economic prestige (average 3.93). Thus, it appears that respondents perceive unethical decisions by 'other' politicians (average 3.83).

In the analysis of the self-control dimension, it is verified that, in general, the sample claims to have good self-control. On average, $20 \%$ of respondent's pre-candidates are at risk of having fun, and they believe that stimulation and adventure are more important to them than safety. They also show that they have reasonable control over their moods and attitudes when they are angry. However, they say they get irritated with some ease. However, in general, it appears that the sample disagreed with the statements that incite deviant behavior.

Regarding the pre-candidate's moral identity, it was identified that most of the respondents' precandidates believe that they do things in their free time (hobbies and activities) that identify them as a person able to hold an elective position in their municipality. However, $60.9 \%$ are actively involved in activities that communicate interest in having an elective office. For moral identity, $71.3 \%$ said they would feel good about having an elective office, $66 \%$ strongly desire to have one elective office in their municipality, and $55.6 \%$ of respondents said that having an elective office is very important to them - an average of 3.53. The analysis of these variables shows that a large part of the respondent pre-candidate desire and demonstrate the desire to hold an elective position in their municipality.

It is also observed that $47 \%$ of respondents do not feel guilty for having bad thoughts, and $43.5 \%$ also do not feel guilty for having some feelings they would not like, with a large percentage, about $48.7 \%$ said they did not if they feel guilt or remorse for feeling jealous. It appears that, in general, respondents' culpability is low, except for variables that involve not having time for family (average 3.33) and not being able to fulfill their obligations (average 3.86).

Regarding the pre-candidate's moral disengagement, it appears that the respondents show a very low propensity (total average of 1.89). However, it is noteworthy that issues that attack family or friends show a slightly greater propensity of some respondents to moral disengagement; $40.9 \%$ of respondents said it is okay to make great efforts to protect their friends who got into trouble. Furthermore, $43.5 \%$ show that it is okay to attack someone who threatens a family's honor. Table 3 analyzes differences between groups. 
Table 3: Difference between groups

\begin{tabular}{|c|c|c|c|c|c|c|}
\hline & & $\begin{array}{l}\text { Unethical } \\
\text { Decision } \\
\text { Making }\end{array}$ & $\begin{array}{l}\text { Individual } \\
\text { Self-control }\end{array}$ & $\begin{array}{c}\text { Moral } \\
\text { Identity }\end{array}$ & Culpability & $\begin{array}{r}\text { Moral } \\
\text { Disengagement }\end{array}$ \\
\hline \multirow{2}{*}{ Gender } & Male & 2,53 & 3,05 & 3,46 & 2,78 & 1,91 \\
\hline & Female & 2,67 & 3,12 & 3,25 & 3,26 & 1,72 \\
\hline \multicolumn{2}{|r|}{ Sig* } & ,262 &, 555 & ,244 & ,009 & ,121 \\
\hline \multirow{3}{*}{$\begin{array}{l}\text { Have you } \\
\text { ever held } \\
\text { an elective } \\
\text { office? }\end{array}$} & Yes & 2,66 & 3,10 & 3,57 & 3,00 & 2,06 \\
\hline & No & 2,49 & 3,05 & 3,29 & 2,82 & 1,72 \\
\hline & Sig* & ,114 & ,667 & ,077 & ,264 & ,001 \\
\hline \multirow{2}{*}{$\begin{array}{l}\text { Marital } \\
\text { Status }\end{array}$} & $\begin{array}{c}\text { Married or Stable } \\
\text { Union }\end{array}$ & 2,54 & 3,06 & 3,47 & 2,85 & 1,85 \\
\hline & Other & 2,61 & 3,09 & 3,27 & 3,01 & 1,89 \\
\hline \multicolumn{2}{|r|}{ Sig.* } &, 530 & ,769 & ,235 & ,346 & ,764 \\
\hline \multirow{3}{*}{$\begin{array}{c}\text { Pre- } \\
\text { candidate }\end{array}$} & Mayor & 2,79 & 3,12 & 3,29 & 2,91 & 1,93 \\
\hline & City councilman & 2,51 & 3,06 & 3,44 & 2,90 & 1,85 \\
\hline & Sig.* &, 044 & ,627 & ,478 & ,943 &, 546 \\
\hline \multirow[b]{2}{*}{ Profession } & Public agent & 2,61 & 2,92 & 3,51 & 3,03 & 1,79 \\
\hline & $\begin{array}{c}\text { Other } \\
\text { (Private) }\end{array}$ & 2,54 & 3,14 & 3,37 & 2,84 & 1,90 \\
\hline & Sig.* & ,569 & ,044 & ,393 & ,283 & ,349 \\
\hline
\end{tabular}

Source: Research Data/ *Significance measured through One-Way Anova.

In Table 3, there is only one statistical difference between the groups: The individual self-control and moral disengagement of those who have already occupied electoral positions and those who have not. In this case, it appears that those who have already held an electoral post have more self-control but are more willing to disengage morally - in comparison with pre-candidates who have not held elective posts previously. There was also a statistical difference between guilt and gender, with women presenting more guilt than men. Furthermore, there were no statistically significant differences between groups.

After this stage, a bivariate analysis was carried out (see table 4) to verify whether there is a correlation (positive or negative) between the variables that explain the propensity to corruption and the profile variables of the pre-candidates. For the analyses, Pearson's linear correlation coefficient was used, given the normality of the data. In the Pearson correlation coefficient (r), as shown in Hair et al. (2005), is considered a: (1) solid relationship when the variation is between 0.91 and 1.00 ; (2) high when the variation is between 0.71 and 0.90; (3) moderate when the variation is 0.41 and 0.70 ; (4) small but defined when it varies between 0.21 and 0.40; and (5) light, almost imperceptible when the variation is between 0.01 and 0.20. 
Table 4: Pearson Correlation Table

\begin{tabular}{|c|c|c|c|c|c|c|c|}
\hline & PTDA & AUTI & IDMO & CULP & DEMO & GEN. & CEAN \\
\hline $\begin{array}{l}\text { Unethical Decision } \\
\text { Making (PTDA) }\end{array}$ & 1 & & & & & & \\
\hline $\begin{array}{c}\text { Individual Self-control } \\
\text { (AUTI) }\end{array}$ & 0,021 & 1 & & & & & \\
\hline $\begin{array}{l}\text { Moral Identity } \\
\text { (IDMO) }\end{array}$ & 0,140 & 0,095 & 1 & & & & \\
\hline Culpability (CULP) & 0,174 & $-0,003$ & 0,141 & 1 & & & \\
\hline $\begin{array}{c}\text { Moral Disengagement } \\
\text { (DEMO) }\end{array}$ & 0,065 & 0,113 & $0,222^{*}$ & $0,254^{* * *}$ & 1 & & \\
\hline Gender (GEN) & 0,106 & 0,056 & $-0,110$ & $0,242^{\text {*** }}$ & $-0,145$ & 1 & \\
\hline $\begin{array}{l}\text { Previous Elective } \\
\text { Position (CEAN) }\end{array}$ & 0,148 & 0,041 & 0,166 & 0,105 & $0,293^{\text {*k }}$ & $-0,105$ & 1 \\
\hline
\end{tabular}

** The correlation is significant at the 0.01 level $(2$ ends). - * Correlation is significant at the 0.05 level ( 2 ends).

After analyzing the correlation data, it was possible to verify a significant and positive association between moral identity and moral disengagement. In other words, moral disengagement is positively related to the variable of holding a previous elective office or not. There is also an association between gender and guilt.

6 DISCUSSIONS

This section of the article is intended to discuss the results, that is, the main advances in the theoretical and practical field. The first discussion that deserves attention is the low participation/representation of women, including as pre-candidates - although it is not different from the average representation of candidates for elections at different political levels. The findings corroborate with the findings of Araújo (2012), who states that women face two disadvantages, based on the initial formal exclusion from citizenship (considering that women have recently obtained the right to vote and participate in politics) and on current exclusion (with participation still unequal with men). In particular, Mazotte (2020) affirmed that the presence of women in the legislature is the lowest among the three branches. The author explains that the female presence is still disproportionate, given that the party defines who will have the most prominent among the candidates, television time, and of course, funding. Nevertheless, according to Araújo (2012), women have difficulties occupying power positions, but when they are elected, there is difficulty in having an active voice in politics.

The second result that deserves attention is the sample's perception of unethical decision-making by politicians. The results show that the sample considers the 'other' politicians predisposed to unethical decision-making, but not themselves. This issue can be explained and corroborated by the findings of Abraham, Suleeman, and Takwin (2018). They argue that in these cases, there is the deactivation of selfregulation. They do not think about monitoring themselves, about controlling themselves to minimize the roles of an individual in the act of corruption. That is, deactivation consists of shifting or diffusing responsibility.

Regarding the self-control of the pre-candidate sample, they generally show a high capacity for self-control, especially the part of the sample that did not hold a previous elective position. The results indicated that individual self-control was positively correlated with culpability and moral disengagement. According to Veloso Gouveia et al. (2013), it is composed of a series of individual principles that make a person prone (or not) to give in to the "temptation" of the crime. It is acquired through socialization, especially the family, in the early stages of life. Although it is difficult to explain why the sample of respondents who have already held electoral positions is less self-controlled, it can be assumed that there may be particular security of action. Because of familiarity, the person can be more willing to assume risks and give in to moral deviations. 
In a nutshell, previous studies have already identified that the variable reelection (mayors in their second term are more corrupt than in the first term) and margin of victory (the more significant the margin, the lower the election competitiveness increases corruption (Batista, 2013). Similarly, there is evidence that mayors who adopt good governance practices tend to be re-elected (Rodrigues \& Rodrigues, 2020). Our study corroborates what was previously presented in the literature.

Concerning guilt, a result that deserves to be highlighted is related to gender. That is, the results of this article showed that women have more guilt than men. Freud (1930/1974) conceived the feeling of guilt as the tension between the ego and the superego, whose function would be to curb the individual's desire for aggression. According to Aquino and Medeiros (2009), the feeling of guilt arises because a person intends or even thinks to do something bad that goes against their ethical and moral principles. Wright (1971) defined guilt as an intolerable affective, directly followed by disrespect, which persists until some balance is restored by reparation or confession and forgiveness. Based on these definitions, it is possible to affirm that women are less prone to decisions that violate ethical and moral precepts or even corruption in electoral positions.

Although the average is relatively low in the dimension of moral disengagement, more than $40 \%$ of respondents are predisposed to disengagement to protect their friends and family. Detert, Trevino, and Sweitzer (2008) claim that individuals with high moral disengagement use cognitive mechanisms to minimize unethical impacts (cognitive dissonance). Consequently, suspending the processes of selfregulation of moral behavior and making fewer complex decisions can be assumed that these individuals can easily take this deviation to other spheres and decisions.

In practical terms, the sample has a low propensity for deviant behavior, that is, corruption. When raising this analysis, which response to the main objective of this study, it is impossible not to have new inherent questions. Why is Brazil one of the most corrupt countries in the world?

\section{LIMITATIONS AND RECOMMENDATIONS FOR FUTURE RESEARCH}

Some limitations must be listed even if the research has achieved its objective. The first limitation is that the number of respondents (although considered an adequate sample) is still tiny. Low participation is related to the exact number of pre-candidates not being known, and there is no pre-registration of this information. Thus, the collection was based on political parties. Even though this survey did not ask the party itself, it may have generated some discomfort/fear in respondents due to the unknown topic. Thus, the total number of candidates was used. The questionnaire could reach an even more significant number of respondents if we knew all the pre-candidates. In addition, because the collection took place during the pandemic period, and a large part of the municipalities have broad limitations, the survey was only applied online (via WhatsApp and e-mail). Of the 25 municipalities where the survey was sent, only 16 responded. That is, $36 \%$ of the municipalities did not return the contact, being possible to obtain more respondents if the contact was made in person.

A non-probabilistic sample, which depends solely on the researcher's criteria with procedures that are much more critical about the validity of their results (Gil, 2008), is also a limitation to be noted.

However, the question of the research theme raises another limitation related to the authenticity of respondents concerning measurable variables that analyze guilt, moral disengagement, and self-control. Respondents could be afraid of being honest (unconsciously or consciously) about such variables.

Furthermore, as it is a fertile field for further research, we may consider solving our limitations and that this one has continuity with the candidates effectively elected in the election. Nevertheless, other forms of analysis of observable variables are recommended, primarily focus groups and experimental studies (to avoid response biases) and obtain a deeper perspective on these behaviors.

Thus, if municipal legislators had little propensity for deviant behavior at the micro-level, a research question that deserves to be investigated is why Brazil is a country with such high levels of corruption. Not 
only but the results of this study also raise the possibility of conducting observational and experimental studies to analyze the propensity of both municipal legislators and political agents to deviant behavior.

Longitudinal studies can bring an approach over time based on evidence of corruption, seeking to correlate moments of more and less corruption with macro-environment variables (political, economic, legal, and technological) and individual variables of legislators - at different levels of public management.

\section{REFERENCES}

Araújo, M. \& Sanchez, O.A. (2005). A corrupção e os controles internos do estado. Lua Nova, 65. https://doi.org/ $10.1590 /$ S0102-64452005000200006

Abraham, J., Suleeman, J., \& Takwin, B. (2018). The psychology of corruption: The role of the counterfeit self, entity self-theory, and outcome-based ethical mindset. Journal of Psychological \& Educational Research, 26(2), 7-32

Albuquerque, B. E., \& Ramos, F. S. (2006). Análise teórica e empírica dos determinantes de corrupção na gestão pública municipal. Encontro Nacional De Economia, XXXIV, Anpec/ Associação Nacional Dos Centros De Pós-Graduação Em Economia. http://www.anpec.org.br/encontro2006/artigos/A06A030.pdf

Andrade, R.S. (2018). Corrupção Municipal e Efeitos do Alinhamento Político com o Governo Federal nas Eleições e nas Condenações. Revista Brasileira de Economia, 72(1), 1-25. https://doi.org/10.5935/0034-7140.20180001

Aquino, K., \& Reed, A. I. (2002). The self-importance of moral identity. Journal of Personality and Social Psychology, 83(6), 1423-1440. https://doi.org/10.1037//0022-3514.83.6.1423

Aquino, T.A.A. \& Medeiros, B. (2009). Escala de culpabilidade: construção e validação de construto. Avaliação Psicológica, 8(1),77-86.

Araújo, C. (2012). Cidadania democrática e inserção política das mulheres. Revista Brasileira de Ciência Política, (9), 147-168. https://doi.org/10.1590/S0103-33522012000300006

Araújo, J. G. N., Moura Soeiro, T., Sobreira de Matos, F. J., \& Gomez Bautista, D. C. (2020). Jeitinho Brasileiro, Corrupção e Contabilidade. Revista Evidenciação Contábil \& Finanças, 8(2). https://doi.org/10.22478/ufpb.2 318-1001.2020v8n2.48165

Bandura, A. (1986). Social foundations of thought and action: A social cognitive theory. Prentice-Hall, Inc. Prentice-Hall series in social learning theory.

Bartels, R. (1967). A Model for Ethics in Marketing. Journal of Marketing, 31(1), 20-26. https://doi.org/10.2307/ 1249296

Batista, M. (2013). Incentivos da dinâmica política sobre a corrupção. Reeleição, competitividade e coalizões nos municípios brasileiros. Revista Brasileira de Ciências Sociais, 28(82), 87-106. https://doi.org/10.1590/S0102-6 9092013000200006

Becker, H. S. (2008). Outsiders: estudos de sociologia do desvio. Rio de Janeiro: Zahar. 232p.

Bendahan, S., Zehnder, C., Pralong, FP, \& Antonakis, J. (2015). Leader corruption depends on power and testosterone. The Leadership Quarterly, 26 (2), 101-122. https://doi.org/10.1016/j.leaqua.2014.07.010

Blasi, A. (1980). Bridging moral cognition and moral action: A critical review of the literature. Psychological bulletin, 88(1), 1. https://doi.org/10.1037/0033-2909.88.1.1

Blasi, A. (1984). Moral Identity: Its Role in Moral Functioning. Em W. M. Kurtines \& J. J. Gewirtz (Eds.), Morality, Moral Behavior and Moral Development (pp. 128-139). New York: John Wiley \& Sons.

Buchaman, J. (1975) Limits of liberty: Between Anarchy and Leviathan. Chicago, University Press.

Carlos, L. G. D. C. (2019). Motivações intrínsecas e extrínsecas na propensão à corrupção de agentes públicos. $61 \mathrm{f}$. Dissertação (Mestrado Profissional em Administração) - Universidade Estadual do Oeste do Paraná, CascavelPR.

Carlos, L.G.C., Ribeiro, I. \& Cintra, R.F. (2020). Motivações na Propensão à Decisões Corruptas em Agentes Públicos. IX Encontro de Estudos em Estratégia - 3Es 2020, $1^{\circ}$ e 2 de setembro de 2020, Evento on-line, Anais... Anpad, Maringá/PR. 
Ivanete Schneider Hahn, et al. Propensity to Corrupt Decisions of Pre-Candidates to the 2020 Brazi...

Cortina, J. M. (1993) What is coefficient alpha? An examination of theory and applications. Journal of Applied Psychology, 78(1), 98-104. https://doi.org/10.1037/0021-9010.78.1.98

Cunha, A. F. D. (2014). Causas e consequências da corrupção: uma breve introdução jurídico-económica. In IV Congresso de Direito Fiscal. Porto: Quid Juris Sociedade.

Da Matta, R. (1982). As raizes da violência no Brasil: reflexóes de um antropólogo social. São Paulo: Brasiliense.

Den Nieuwenboer, N. A., \& Kaptein, M. (2008). Spiraling down into corruption: A dynamic analysis of the social identity processes that cause corruption in organizations to grow. Journal of Business Ethics, 83(2), 133-146. h ttps://doi.org/10.1007/s10551-007-9617-8

Detert, JR, Treviño, LK, \& Sweitzer, VL (2008). Moral disengagement in ethical decision making: a study of antecedents and outcomes. Journal of Applied Psychology, 93 (2), 374-391. https://doi.org/10.1037/0021-901 0.93.2.374

Donato, L. (2018). Behavioural research and corruption: A new promise for governments? European Law Journal, 24(6), 510-523. https://doi.org/10.1111/eulj.12218

Eisenhardt, K.M. (1989) Agency theory: an assessment and review. Academy of Management Review, 14 (1), 57-74 h ttps://doi.org/10.2307/258191

Ferrell, O. C., \& Gresham, L. G. (1985). A contingency framework for understanding ethical decision making in marketing. Journal of marketing, 49(3), 87-96. https://doi.org/10.1177/002224298504900308

Freitas, H., Oliveira, M., Saccol, A. Z., \& Moscarola, J. (2000). O método de pesquisa survey. RAUSP Management Journal, 35(3), 105-112.

Freud, S. (1974). O mal-estar da civilização. Rio de Janeiro: Imago Editore LTDA.

Frost, J., \& Tischer, S. (2014). Unmasking Collective Corruption: The Dynamics of Corrupt Routines, European Management Review, 11 (3-4), 191-207. https://doi.org/10.1111/emre.12034

Gabardo, E., \& Reis, L. E. (2011). O gerencialismo entre eficiência e corrupção: breves reflexões sobre os percalços do desenvolvimento. Fórum Administrativo: Direito Público, 11(124), 39-50

Gil, A. C. (2008). Métodos e técnicas de pesquisa social. 6. ed. Editora Atlas SA.

Gonçalves, V. B. \& Andrade, D. M. (2019). A corrupção na perspectiva durkheimiana: um estudo de caso da Operação Lava Jato. Revista de Administração Pública, 53(2), 271-290. http://dx.doi.org/10.1590/0034-761220180192

Hair, Jr., Babin, B., Money, A., \& Samouel, P. (2005). Fundamentos de métodos depesquisa em administração. Bookman Companhia Ed.

Hendriksen, E.S. \& Van Breda, M. F. (1999) Teoria da contabilidade. São Paulo: Atlas.

Índice de Percepção da Corrupção (IPC) (2020). Corruption Perceptions Index. Retrieved January 10, 2021, from: h ttps://www.transparency.org/en/cpi/2020/index/nzl

Índice de Percepção da Corrupção 2019. IPC 2019: Américas. Retrieved January 10, 2021, from: https://transparen ciainternacionalbr.medium.com/ipc-2019-am\%C3\%A9ricas-854d8e1979d0

Jensen, M. C. \& Meckling, W.H. (1976). Theory of the firm: managerial behavior, agency costs and ownership structure. Journal of Financial Economics, 3(4), 305-360. https://doi.org/10.1016/0304-405X(76)90026-X

Köbis, N. C., van Prooijen, J. W., Righetti, F., \& Van Lange, P. A. (2016). Prospection in individual and interpersonal corruption dilemmas. Review of General Psychology, 20(1), 71-85. https://doi.org/10.1037/gpr0000069

Kohlberg, L. (1969). Stage and sequence: The cognitive development approach to socialization. In D. A. Goslin (Ed.). Handbook of socialization theory (p. 347-480). Chicago, IL, Rand McNally.

Lange, D. (2008). A multidimensional conceptualization of organizational corruption control. Academy of Management Review, 33(3), 710-729. https://doi.org/10.2307/20159432

Likert, R. (1932). A technique for the measurement of attitudes. Archives of Psychology, 22, pp.5-55. Retrieved January 19, 2021, from: https://legacy.voteview.com/pdf/Likert_1932.pdf

Luciano, E. M., Wiedenhöft, G. C., \& Callegaro, S. (2019). Entendendo os fatores de combate à corrupção: proposta de um constructo de dissuasão à corrupção. Revista de Contabilidade e Organizações, 13, 19-30. https://doi.org /10.11606/issn.1982-6486.rco.2019.158516 
Macedo, S., \& Valadares, J. (2020). De Samba-Enredo De Carnaval Ao Congresso Nacional: Reflexões Sobre A Lei De Acesso À Informação Frente Ao Controle Da Corrupção No Brasil. Holos, 4, 1-24. https://doi.org/10.156 28/holos.2020.9786

Mânica, J. M. (2012). As manobras do comportamento desviante. Dissertação de Mestrado, Pontifícia Universidade Católica do Rio Grande do Sul- PUC/RS, Porto Alegre/RS.

Mazotte, N. (2020). Legislativo é o mais desigual dos três poderes em representação feminina. Retrieved march 02, 2021, from: http://www.generonumero.media/legislativo-e-o-mais-desigual-em-representacao-feminina-dos-tr es-poderes/

Mead, N. L., Baumeister, R. F., Gino, F., Schweitzer, M. E., \& Ariely, D. (2009). Too tired to tell the truth: Self-control resource depletion and dishonesty. Journal of Experimental Social Psychology, v. 45, 594-597. https://doi.org/1 0.1016/j.jesp.2009.02.004

Medeiros, C. R. O. \& de Freitas, L. R. Jr. (2019). Padrões discursivos sobre corrupção. Revista de Contabilidade e Organizações, 13, e152220-e152220. https://doi.org/10.11606/issn.1982-6486.rco.2019.152220

Medeiros, H. \& Forte, S.H.A.C. (2019). Influência Da Corrupção Percebida Na Legitimidade Das Ações Públicas. Anais do Encontro Nacional da Associação Nacional de Pós-Graduação e Pesquisa em Administração, São Paulo, Brasil, 43.

Modesto, J. G. N. (2018). “Por que corruptos são corruptos?”: Propositura e apresentação de evidências do Modelo Analítico da Corrupção. 171 f., Tese (Doutorado em Psicologia Social, do Trabalho e das Organizações) - Universidade de Brasília, Brasília.

Moore, C. (2008). Moral disengagement in processes of organizational corruption. Journal of Business Ethics, 80(1), 129-139. https://doi.org/10.1007/s10551-007-9447-8

Pelletier, K. L., \& Bligh, M. C. (2006). Rebounding from corruption: Perceptions of ethics program effectiveness in a public sector organization. Journal of Business Ethics, 67(4), 359-374. https://doi.org/10.1007/s10551-0069027-3

Rabl, T. \& Kuhlmann, T. M. (2009) Why or why not? Rationalize corruption in organizations. Cross Cultural Management International Journal, 16(3): 268-286. https://doi.org/10.1108/13527600910977355

Resende, M.M., \& Porto, J.B. (2017). Escala de Identidade Moral: Evidências de Validade para o Contexto Brasileiro. Psico-USF, 22(1), 75-85. https://doi.org/10.1590/1413-82712017220107

Reynolds, S. J., \& Ceranic, T. L. (2007). The effects of moral judgment and moral identity on moral behavior: An empirical examination of the moral individual. Journal of Applied Psychology, 92(6), 1610-1624. https://doi.or $\mathrm{g} / 10.1037 / 0021-9010.92 .6 .1610$

Ritt, C. F., \& Ritt, E. (2018). A corrupção na administração pública brasileira como consequência do modelo de gestão patrimonialista por ela adotado e a necessidade de haver códigos de ética pública. Revista de Direito Administrativo e Gestão Pública, 4(2), 1-20. http://dx.doi.org/10.26668/IndexLawJournals/2526-0073/2018 .v4i2.4703

Rodrigues, A. C., \& Rodrigues, S. B. (2019). Governança pública e reeleições municipais em Minas Gerais. Administração Pública e Gestão Social, 12(1), https://doi.org/10.21118/apgs.v12i1.5682

Sallaberry, J.D. \& Flach, L. (2019). Determinantes econômicos contemporâneos para a escolha dos líderes da administração pública brasileira. Ler. Revista Eletrônica de Administração (Porto Alegre), 25 (2), 119-149. http s://doi.org/10.1590/1413-2311.242.89611

Sodré, R. J. M. (2017). Sobre corruptos, corrompidos e culpados: relatos de servidores públicos sobre práticas de corrupção. Revista de Contabilidade e Organizaçôes, 11(31), 21-30. https://doi.org/10.11606/rco.v11i31.1344 65

Souza, F. J. B., de Almeida Midlej, S., \& de Gomes, A.O. (2019). Corrupção no Setor Público: Agenda de Pesquisa e Principais Debates a Partir da Literatura Internacional. Administração Pública e Gestão Social, 1-18. http://ww w.redalyc.org/articulo.oa?id=351559268001

Sturm, R. E., \& Antonakis, J. (2015). Interpersonal power: A review, critique, and research agenda. Journal of Management, 41(1), 136-163. https://doi.org/10.1177/0149206314555769 
Ivanete Schneider Hahn, et al. Propensity to Corrupt Decisions of Pre-Candidates to the 2020 Brazi...

Tavits, M. (2010). Why do people engage in corruption? The case of Estonia. Social Forces, 88(3), 1257-1279. http s://doi.org/10.1353/sof.0.0288

Tenbrunsel, A. E., \& Messick, D. M. (2004). Ethical fading: The role of self-deception in unethical behavior. Social Justice Research, 17(2), 223-236. https://doi.org/10.1023/B:SORE.0000027411.35832.53

Úbeda, F., \& Duéñez - Guzmán, E. A. (2010). Power and corruption. Evolution: International Journal of Organic Evolution, 65(4), 1127-1139. https://doi.org/10.1111/j.1558-5646.2010.01194.x

Veloso Gouveia, V., dos Santos, W. S., Martins Guerra, V., da Fonseca, P. N., \& Veloso Gouveia, R. S. (2013). Escala de Autocontrole: adaptação brasileira e evidências de validade de construto. Avalição Psicológica, 12(3). http:// www.repositorio.ufc.br/handle/riufc/19860

Wright, D. (1971). The psychology of moral behavior. New York: Penguin Books. 


\section{Appendix}

Table 5: Perception of unethical decision making

\begin{tabular}{|c|c|c|c|c|c|c|c|}
\hline \multirow{2}{*}{$\begin{array}{l}\text { Observable } \\
\text { Variable }\end{array}$} & \multirow{2}{*}{ Mean } & \multirow{2}{*}{$\begin{array}{l}\text { Standard } \\
\text { Deviation }\end{array}$} & \multicolumn{5}{|c|}{ Frequency (\%) } \\
\hline & & & 1 & 2 & 3 & 4 & 5 \\
\hline $\begin{array}{l}\text { You notice } \\
\text { that there are } \\
\text { politicians } \\
\text { who let } \\
\text { themselves be } \\
\text { carried away } \\
\text { by whims, } \\
\text { affection or } \\
\text { personal } \\
\text { interests, } \\
\text { sympathies } \\
\text { and dislikes } \\
\text { when dealing } \\
\text { with the } \\
\text { public or with } \\
\text { other } \\
\text { colleagues. }\end{array}$ & 4.05 & 1.074 & 6.1 & 1.7 & 13 & 39.1 & 40 \\
\hline $\begin{array}{l}\text { Some } \\
\text { politicians } \\
\text { have a } \\
\text { practice of } \\
\text { deliberately } \\
\text { damaging the } \\
\text { reputation of } \\
\text { other servants } \\
\text { or citizens } \\
\text { who depend } \\
\text { on them. }\end{array}$ & 3.90 & 1.162 & 7 & 5.2 & 14.8 & 36.5 & 36.5 \\
\hline $\begin{array}{l}\text { You notice } \\
\text { that some } \\
\text { politician } \\
\text { treats some } \\
\text { public service } \\
\text { users } \\
\text { differently } \\
\text { (according to } \\
\text { the user's } \\
\text { social or } \\
\text { economic } \\
\text { prestige). }\end{array}$ & 3.93 & 1.211 & 7 & 7.8 & 11.3 & 33 & 40.9 \\
\hline $\begin{array}{l}\text { You notice } \\
\text { that } \\
\text { politicians } \\
\text { eventually } \\
\text { accept gifts } \\
\text { from } \\
\text { taxpayers or } \\
\text { company } \\
\text { representatives } \\
\text { for their great } \\
\text { efforts. }\end{array}$ & 3.46 & 1.223 & 8.7 & 11.3 & 29.6 & 26.1 & 24.3 \\
\hline
\end{tabular}

Source: Research Data. 
Ivanete Schneider Hahn, et al. Propensity to Corrupt Decisions of Pre-Candidates to the 2020 Brazi...

Table 6: Analysis of the individual self-control dimension

\begin{tabular}{|c|c|c|c|c|c|c|c|}
\hline \multirow{2}{*}{$\begin{array}{l}\text { Observable } \\
\text { Variable }\end{array}$} & \multirow{2}{*}{ Mean } & \multirow{2}{*}{$\begin{array}{l}\text { Standard } \\
\text { Deviation }\end{array}$} & \multicolumn{5}{|c|}{ Frequency (\%) } \\
\hline & & & 1 & 2 & 3 & 4 & 5 \\
\hline $\begin{array}{l}\text { I don't take } \\
\text { risks just for } \\
\text { fun. }\end{array}$ & 4.29 & 1.284 & 3.5 & 14.8 & 6.1 & - & 75.7 \\
\hline $\begin{array}{l}\text { For me, } \\
\text { stimulation } \\
\text { and adventure } \\
\text { are not more } \\
\text { important } \\
\text { than safety. }\end{array}$ & 4.27 & 1.314 & 2.6 & 19.1 & 2.6 & - & 75.7 \\
\hline $\begin{array}{l}\text { I don't like to } \\
\text { test myself by } \\
\text { doing risky } \\
\text { things. }\end{array}$ & 3.58 & 1.583 & 7.0 & 32.2 & 8.7 & - & 52.2 \\
\hline $\begin{array}{l}\text { When I have a } \\
\text { disagreement } \\
\text { with someone, } \\
\text { I don't get } \\
\text { upset just } \\
\text { talking about } \\
\text { it. }\end{array}$ & 2.83 & 1.413 & 24.3 & 20.0 & 19.1 & 20.9 & 15.7 \\
\hline $\begin{array}{l}\text { When I'm } \\
\text { really angry, I } \\
\text { control myself } \\
\text { and people } \\
\text { don't need to } \\
\text { stay away } \\
\text { from me. }\end{array}$ & 1.80 & 1.075 & 52.2 & 27 & 13 & 3.5 & 4.3 \\
\hline $\begin{array}{l}\text { I don't get } \\
\text { irritated easily. }\end{array}$ & 1.66 & 0.944 & 57.4 & 27 & 9.6 & 4.3 & 1.7 \\
\hline
\end{tabular}

Source: Research Data. 
Table 7: Analysis of the pre-candidate's moral identity dimension

\begin{tabular}{|c|c|c|c|c|c|c|c|}
\hline \multirow{2}{*}{$\begin{array}{l}\text { Observable } \\
\text { Variable }\end{array}$} & \multirow{2}{*}{ Mean } & \multirow{2}{*}{$\begin{array}{l}\text { Standard } \\
\text { Deviation }\end{array}$} & \multicolumn{5}{|c|}{ Frequency (\%) } \\
\hline & & & 1 & 2 & 3 & 4 & 5 \\
\hline $\begin{array}{l}\text { The kinds of } \\
\text { things I do in } \\
\text { my spare } \\
\text { time (hobbies } \\
\text { and activities) } \\
\text { clearly } \\
\text { identify me } \\
\text { as a person } \\
\text { able to hold } \\
\text { an elected } \\
\text { office in my } \\
\text { municipality. }\end{array}$ & 4.11 & 1.049 & 3.5 & 4.3 & 15.7 & 30.4 & 46.1 \\
\hline $\begin{array}{l}\text { I am actively } \\
\text { involved in } \\
\text { activities that } \\
\text { communicate } \\
\text { to others that } \\
\text { I am } \\
\text { interested in } \\
\text { having an } \\
\text { elected office } \\
\text { in my } \\
\text { municipality. }\end{array}$ & 3.69 & 1.319 & 7.8 & 13.9 & 17.4 & 22.6 & 38.3 \\
\hline $\begin{array}{l}\text { My } \\
\text { membership } \\
\text { in certain } \\
\text { organizations } \\
\text { conveys to } \\
\text { others that I } \\
\text { am a person } \\
\text { with an } \\
\text { interest in } \\
\text { holding an } \\
\text { elected office } \\
\text { in my } \\
\text { municipality. }\end{array}$ & 3.16 & 1.492 & 21.7 & 13 & 17.4 & 22.6 & 25.2 \\
\hline $\begin{array}{l}\text { I usually wear } \\
\text { clothes that } \\
\text { identify me } \\
\text { as someone } \\
\text { who is } \\
\text { interested in } \\
\text { holding an } \\
\text { elected office } \\
\text { in my county. }\end{array}$ & 2.02 & 1.273 & 52.2 & 14.8 & 16.5 & 11.3 & 5.2 \\
\hline $\begin{array}{l}\text { The types of } \\
\text { books and } \\
\text { magazines I } \\
\text { read identify } \\
\text { me as a } \\
\text { person } \\
\text { interested in } \\
\text { holding an } \\
\text { elected office } \\
\text { in my } \\
\text { municipality. }\end{array}$ & 2.93 & 1.261 & 18.3 & 15.7 & 33 & 20.9 & 12.2 \\
\hline $\begin{array}{l}\text { I would feel } \\
\text { good to have } \\
\text { an elective } \\
\text { office in my } \\
\text { municipality. }\end{array}$ & 3.99 & 1.203 & 7 & 4.3 & 17.4 & 25.2 & 46.1 \\
\hline $\begin{array}{l}\text { I strongly } \\
\text { desire to have } \\
\text { an elective } \\
\text { office in my } \\
\text { municipality. }\end{array}$ & 3.85 & 1.312 & 9.6 & 6.1 & 18.3 & 21.7 & 44.3 \\
\hline $\begin{array}{l}\text { Having an } \\
\text { elective } \\
\text { (political) } \\
\text { position in } \\
\text { my } \\
\text { municipality } \\
\text { is important } \\
\text { to me. }\end{array}$ & 3.53 & 1.319 & 11.3 & 9.6 & 23.5 & 25.2 & 30.4 \\
\hline
\end{tabular}


Ivanete Schneider Hahn, et al. Propensity to Corrupt Decisions of Pre-Candidates to the 2020 Brazi...

Source: Research Data.

Table 8: Analysis of the culpability dimension

\begin{tabular}{|c|c|c|c|c|c|c|c|}
\hline \multirow{2}{*}{$\begin{array}{l}\text { Observable } \\
\text { Variable }\end{array}$} & \multirow{2}{*}{ Mean } & \multirow{2}{*}{$\begin{array}{l}\text { Standard } \\
\text { Deviation }\end{array}$} & \multicolumn{5}{|c|}{ Frequency (\%) } \\
\hline & & & 1 & 2 & 3 & 4 & 5 \\
\hline $\begin{array}{l}\text { I feel guilty } \\
\text { for having } \\
\text { "bad } \\
\text { thoughts" } \\
\text { sometimes. }\end{array}$ & 2.60 & 1.226 & 23.5 & 23.5 & 29.6 & 15.7 & 7.8 \\
\hline $\begin{array}{l}\text { I feel guilty } \\
\text { for having } \\
\text { some feelings } \\
\text { I don't like. }\end{array}$ & 2.75 & 1.232 & 18.3 & 25.2 & 29.6 & 16.5 & 10.4 \\
\hline $\begin{array}{l}\text { I feel guilty } \\
\text { when I'm } \\
\text { jealous. }\end{array}$ & 2.64 & 1.528 & 37.4 & 11.3 & 17.4 & 17.4 & 16.5 \\
\hline $\begin{array}{l}\text { I regret doing } \\
\text { something I } \\
\text { shouldn't } \\
\text { have done. }\end{array}$ & 2.85 & 1.434 & 26.1 & 16.5 & 19.1 & 22.6 & 15.7 \\
\hline $\begin{array}{l}\text { I feel remorse } \\
\text { for having } \\
\text { done } \\
\text { something I } \\
\text { shouldn't. }\end{array}$ & 2.65 & 1.445 & 31.6 & 20 & 13.9 & 21.7 & 13 \\
\hline $\begin{array}{l}\text { When I can't } \\
\text { do my duties } \\
\text { on time, I feel } \\
\text { guilty. }\end{array}$ & 3.86 & 1.269 & 8.7 & 7 & 14.8 & 28.7 & 40.9 \\
\hline $\begin{array}{l}\text { I feel guilty } \\
\text { for not } \\
\text { having the } \\
\text { willpower to } \\
\text { carry out my } \\
\text { purposes. }\end{array}$ & 2.52 & 1.397 & 33.9 & 19.1 & 19.1 & 16.5 & 11.3 \\
\hline $\begin{array}{l}\text { I usually feel } \\
\text { guilty about } \\
\text { not having } \\
\text { time for the } \\
\text { people I love. }\end{array}$ & 3.33 & 1.401 & 17.4 & 9.6 & 19.1 & 29.6 & 24.3 \\
\hline
\end{tabular}

Source: Research Data.

Table 9: Analysis of the moral disengagement dimension

\begin{tabular}{|c|c|c|c|c|c|c|c|}
\hline \multirow{2}{*}{ Observable Variable } & \multirow{2}{*}{ Mean } & \multirow{2}{*}{$\begin{array}{l}\text { Standard } \\
\text { Deviation }\end{array}$} & \multicolumn{5}{|c|}{ Frequency (\%) } \\
\hline & & & 1 & 2 & 3 & 4 & 5 \\
\hline It's okay to make great efforts to protect your friends who got into trouble. & 2.91 & 1.460 & 26.1 & 14.8 & 18.3 & 23.5 & 17.4 \\
\hline It's okay to attack someone who threatens your family's honor. & 2.73 & 1.422 & 29.6 & 13.9 & 25.2 & 16.5 & 14.8 \\
\hline Talking about people behind their backs is only part of the game. & 1.39 & 0.823 & 75.7 & 14.8 & 6.1 & 1.7 & 1.7 \\
\hline $\begin{array}{l}\text { It's okay to copy a friend's work without permission. It would be like } \\
\text { borrowing something. }\end{array}$ & 1.30 & 0.739 & 81.7 & 10.4 & 3.5 & 4.3 & 0 \\
\hline $\begin{array}{l}\text { Stealing a little money is not very serious compared to those who steal a lot of } \\
\text { money. }\end{array}$ & 1.21 & 0.814 & 91.3 & 3.5 & 0.9 & 0.9 & 3.5 \\
\hline $\begin{array}{l}\text { Compared to other illegal things people do, taking some things from a store } \\
\text { without paying is not very serious. }\end{array}$ & 1.19 & 0.724 & 91.3 & 4.3 & 0 & 2.6 & 1.7 \\
\hline $\begin{array}{l}\text { If people are living in bad conditions, they cannot be blamed for behaving } \\
\text { aggressively. }\end{array}$ & 2.09 & 1.221 & 42.6 & 25.2 & 19.1 & 6.1 & 7 \\
\hline $\begin{array}{l}\text { A member of a group or team should not be held responsible for the } \\
\text { problems the team caused. }\end{array}$ & 2.77 & 1.389 & 23.5 & 22.6 & 23.5 & 13.9 & 16.5 \\
\hline Teasing someone really doesn't hurt. & 1.35 & .763 & 77.4 & 13 & 7 & 1.7 & 0.9 \\
\hline If someone leaves something lying around, it's their fault if it's stolen. & 1.87 & 1.260 & 60 & 13.9 & 10.4 & 10.4 & 5.2 \\
\hline People who are mistreated often do things to deserve it. & 1.72 & .941 & 54.8 & 23.5 & 18.3 & 1.7 & 1.7 \\
\hline
\end{tabular}


Administração Pública e Gestão Social, 2022, vol. 14, NúM. 1, Enero-Marzo, ISSN: 2175-5787

Source: Research Data. 